\title{
Adrenomedullin Prevents Lung Injury after Hepatic Ischemia-Reperfusion Damage
}

\author{
Adrenomedullin Hepatik İskemi-Reperfüzyon Hasarı Sonrası Akciğer Hasarını Önler
}

\section{Kursat Dikmen, Hasan Bostanci, Aydin Yavuz, Huseyin Gobut, Murat Alper, Mustafa Kerem}

${ }^{1}$ Gazi University, School of Medicine, Department of Genaral Surgery, Ankara, Turkey

${ }^{2}$ Yildirim Beyazit University, Yenimahalle Training and Research Hospital, Department of Genaral Surgery, Ankara, Turkey

${ }^{3}$ Diskapi Yildirim Bayezit Training and Education Hospital, Department of Pathology, Ankara, Turkey

\section{ABSTRACT}

Objective: Acute lung injury is a complication after hepatic ischemia/reperfusion (I/R) and might be responsible for high mortality rate. The aim of this study was to demonstrate that adrenomedulline administration may prevent lung injury after hepatic I / R by downregulation of proinflammatory cytokines.

Materials and Methods: This study was performed by using 54 male Wistar rats. The rats were randomly allocated into 3 groups and in groups were randomly allocated into 1 st, 2 nd, and 4 th hour subgroups. After I/R, AM $(12 \mu \mathrm{g} / \mathrm{kg})$ was infused for 30 minute via portal vein. Blood and tissue samples were collected 1, 2 and 4 hour after reperfusion. Hepatic I/R induced lung injury, as characterized by lung edema, histopathologic changes and proinflammatory cytokines including tumor necrosis factor- $\alpha$ (TNF- $\alpha$ ) and interleukin-6 (IL-6) levels were evaluated.

Results: The TNF- $\alpha$ enzyme activity in the first hour was found to be significantly higher in the I/R group than in the Sham and AM group $(p=0.027$ and $p=0.041$, respectively). The levels of TNF- $\alpha$ in the sham-operated group were similar in the AM group $(p=0.310)$. Significant differences were found only in the second hour IL- 6 measurements $(p=0.038)$. Similar differences in caspase-9 enzyme activity in the sham-operated and AM group $(p=0.291)$. Treatment with AM decreased lung injury after hepatic I/R as demonstrated by reduction in histologic damage.

Conclusions: Acute lung injury was decreased by AM treatment after hepatic I/R injury.

Key Words: Adrenomedullin, hepatic ischemia/reperfusion, lung injury.

Received: 11.03 .2018

Accepted: 11.13 .2018

\section{ÖZET}

Amaç: Akut akciğer hasarı, hepatik iskemi/reperfüzyon (I/R) sonrası görülen bir komplikasyondur ve yüksek mortalite oranlarından sorumludur. Bu çalışmanın amacı, adrenomedüllin uygulamasının hepatik I/R sonrası akciğer hasarını proinflamatuar sitokinlerin downregüle edilmesi yolu ile önleyebileceğini göstermektir.

Yöntemler: Bu çalışma 54 erkek Wistar rat kullanılarak gerçekleştirildi. Ratlar randomize olacak şekilde 3 gruba ayrıldı. Bu gruplar tedavi veya I/R'dan sonra 1., 2. ve 4. saat alt gruplarına ayrıldı. İskemi sonlandırıldıktan sonra, AM $(12 \mu \mathrm{g}$ / kg) portal ven yoluyla 30 dakika verildi. Kan ve doku örnekleri reperfüzyondan 1,2 ve 4 saat sonra toplandı. Akciğer ödemi, histopatolojik değişiklikler ve plazma tümör nekroz faktör- $\alpha$ (TNF- $\alpha$ ) ve interlökin-6 (IL-6) gibi proinflamatuar sitokin düzeyleri değerlendirildi.

Bulgular: Birinci saatteki TNF- $\alpha$ enzim aktivitesi I/R grubunda, Sham ve AM grubundan anlamlı olacak şekilde daha yüksek bulundu (sırasıyla, $p=0.027$ ve $p=0.041$ ). Sham grubundaki TNF- $\alpha$ seviyeleri, AM grubu ile benzer bulundu ( $p$ $=0.310$ ). I ikinci saat IL-6 ölçümlerinde subgruplar arasında istatistiksel olarak anlamlı farklılık bulundu ( $p=0.038$ ). Sham ve AM grubunda caspase- 9 enzim aktivitesi bakımından görülen fark istatistiksel olarak anlamlı bulunmad $(p=0.291)$. Adrenomedullin grubunda gözlenen histolojik hasar hepatic $I / R$ grubuna göre daha az olduğu gösterildi.

Sonuç: Hepatik I/R hasarı sonrası oluşan akut akciğer hasarı adrenomedullin uygulanması ile azaltılabilir.

Anahtar Sözcükler: Adrenomedullin, hepatic ischemia/reperfusion, akciğer hasarı.

Geliş Tarihi: 03.11.2018

Kabul Tarihi: 13.11 .2018 
INTRODUCTION

One of the difficulties arising in the post-operative period after liver transplantation and liver resection is lung injury. Lung injury after liver surgery is a serious complication affecting the prognosis of patients. Meanwhile, lung injury cause leads to death $(1,2)$. It was observed that pulmonary edema developed within hours especially after liver transplantation. It was reported in experiments with animals that there were increased flow of neutrophil and pulmonary septal thickening after temporary hepatic artery clamping (3). This injury occurring in the lung is attributed to hepatic I/R injury. This may cause lung injury and related complications $(4,5)$. Pro-inflammatory and anti-inflammatory cytokines are released in consequence of the activation in hepatic Kupffer cells forming during $I / R$, and oxygen radicals are generated (6). Many cytokines such as TNF- $\alpha$, IL- $1 \beta$, IL- 6 , prostaglandins and reactive oxygen products released during blood circulation first come to the capillary laver of the lung after circulation (7,8). Many different methods such as ischaemic preconditioning, remote pre-conditioning and various agents pharmacologically were tried so as to prevent hepatic I/R injury and they are still being tried (9). Of these precautions, surgical techniques are restricted or impossible to implement in some cases. Therefore, trying pharmacological agents in reducing hepatic $\mathrm{I} / \mathrm{R}$ is considered as a more acceptable method. However, no molecules preventing distant organ damage such as liver occurring after hepatic I/R.

Adrenomedullin was introduced into the world of science for the first time in 1923 as a molecule having the structure of a peptide composed of 52 amino acids (10). It has been used in many diseases such as sepsis, shock, rheumatoid arthritis and inflammatory intestinal diseases in whose pathophysiology inflammation took on important responsibilities since that date (11). Later, it was found that AM had many biological activities such as vasodilatation, bronchodilatation, diuretic effects, aldosterone secretion inhibition, neurotransmission and anti-microbial effects (12). The effects of $\mathrm{AM}$ on inflammation have been the focus especially in recent years. Many clinical and animal experiments indicating that AM expression increase in acute liver damage $(13,14)$. It was demonstrated that it was expressed especially in bronchial epithelium, bronchial smooth muscle, pulmonary vascular structures and macrophage (11). Besides, its anti-inflammatory effects were also shown in some liver disease models (14). The aim of the present study was to evaluate the effect of AM administration after hepatic $\mathrm{I} / \mathrm{R}$ induced lung injury in rats.

\section{MATERIALS AND METHODS}

This experiment were reviewed and approved by the Institutional Animal Care and Use Committee at Gazi University (Protocol No: G.U.E.T-05052). All animal procedures in this study were conducted in accordance with the Principles of Laboratory Animal Care formulated by the National Society for Medical Research and the Guide for the Care and Use of Laboratory Animals prepared by the Institute of Laboratory Animal Resources.

\section{Animals and Study Design}

This study was performed by using 54 male Wistar rats, weighting 220-270 gram. The animals were housed for at least 5 day before surgery, with free access to a standard diet and water on 12 hours of light and 12 hours of dark in individual cages. All experiments were performed with rats that had fasted for 12 hours before surgery and all procedures were performed using sterile surgical technique. Following randomization, the rats were divided into three groups. Rats were subjected to 1 hour of $70 \%$ hepatic ischemia following reperfusion. At the end of the ischemia, AM was infused via the portal vein. After the ischemia blood samples rom inferior vena cava were taken. Siz rats from each group were sacrified in the $1^{\text {st }}, 2^{\text {nd }}$ and $4^{\text {th }}$ hours reperfusion and histopathological examination of lungs was performed.

Sham Group $(n=18)$ : No ischemia and reperfusion was performed. Only blood and lung tissue samples of rats were taken.

Control (I/R) Group ( $n=18)$ : Reperfusion was performed after 1 hour of partial ischemia, and $1 \mathrm{ml}$ mean (phosphate-buffered saline solution) was infused over 10 minute via the portal vein immediately upon reperfusion. $1^{\text {st }}$, $2^{\text {nd }}$ and $4^{\text {th }}$ hours subgroups ( $n=6$ per group and time point) of rats' blood samples and lung tissue samples were taken.

AM treatment Group ( $n=18)$ : Reperfusion was performed after 1 hour of partial ischemia, and AM (12 $\mathrm{\mu g} / \mathrm{kg}$ BW; Phoenix Pharmaceuticals, Belmont, CA, USA) was infused for 30 minute via the portal vein immediately upon reperfusion. $1^{\text {st }}, 2^{\text {nd }}$ and $4^{\text {th }}$ hours subgroups ( $n=6$ per group and time point) of rats' blood samples and lung tissue samples were taken.
Anesthesia and Surgical Procedure

Rats were anesthetized with intraperitoneal ketamine $[100 \mathrm{mg} / \mathrm{kg}$ body weight (BW)] and xylazine $(20 \mathrm{mg} / \mathrm{kg})$ and prepared for aseptic surgery. A midline incision extending from the xiphoid to the pubis was made. A polyethylene catheter (PE-50, ID 0.28, OD 0.61; Portex, Hyte, UK) was inserted into the ileocecal vein to the portal vein for infusion of the drugs. The liver was exposed with retractors placed in the flank, and a clamp was attached to the xiphoid and elevated. The ligamentous attachments from the liver to the diaphragm were freed. In order to avoid splanchnic congestion, we used a model of partial liver ischemia. Partial liver ischemia was induced by selective clamping of the portal vein and hepatic artery, which supply the left lateral and median lobes of the liver (segments II-IV), using an atraumatic vascular clamp (Harvard Apparatus Inc., Hollinston, MA, USA) for 1 hour, followed by different periods of reperfusion.

\section{Blood Analysis}

Blood samples were collected from the vena cava in Sham groups $\left(1^{\text {st }}, 2^{\text {nd }}\right.$ and $4^{\text {th }}$ hours). To separate plasma the samples were centrifuged at 3000 revolutions for 10 minutes and blood samples were stored at $-80{ }^{\circ} \mathrm{C}$ until assayed. To determine the levels of TNF- $\alpha$ and IL-6, a commercial solid phase sandwich enzyme-linked immunosorbent assay (ELISA) from Biosource International (Camarillo, CA, USA) was used. TNF- $\alpha$ levels were determined from a standard curve for recombinant TNF- $\alpha$ and; concentrations were expressed as pg/ml. The ELISA detection limit for TNF- $\alpha$ was $3 \mathrm{pg} / \mathrm{ml}$.

\section{Immunohistochemistry}

Lung tissue samples were taken from the rats in the Sham operated group $1^{\text {st }}, 2^{\text {nd }}$ and $4^{\text {th }}$ hours after laparotomy or lung tissue samples were taken only from the rats in hepatic $1 / R+A M$ sub-groups in the $1^{\text {st }}, 2^{\text {nd }}$ and $4^{\text {th }}$ hours following the 30 minute infusion. Resected lung tissue was fixed in $10 \%$ buffered formalin for 7 days and embedded in paraffin. Sections of 3- $\mu \mathrm{m}$ thickness were obtained from the paraffin blocks and stained with H\&E for histological examination. The sections were placed onto polylysine plates and immunohistochemically dyed with Caspase-9 primer antibody (Caspase 9/ LAP 6, Ab-6, Ca+ $\neq$ RB- 1570- PO Labvision/ Neo Markers Corporation, Fremont, CA, 94539 USA). The degree of immunoreactivity with Caspase- 9 was evaluated as follows: $(-)$ : nill, $(+)$ : mild, $(++)$ : moderate, $(+++)$ : strong.

\section{Light Microscopy Evaluation}

Morphologic alterations in the lungs ere examined at $1^{\text {st }}, 2^{\text {nd }}$ and $4^{\text {th }}$ hours after completion of treatment by light microscopy. The samples of the lung tissue obtained from the sham-operated, control I/R and AM treatment groups were fixed in $10 \%$ for 72 hours. Then, they were washed in alcohols of various degrees and embedded in paraffin. Sections of $3 \mu \mathrm{m}$ thicknesses were obtained from the paraffin blocks and were stained with H\&E. Morphologic examinations were performed in a blinded fashion using a Leica DM 4000B microscope and documented by photographs.

\section{Statistical Analysis}

SPSS 20.0 programme (IBM, Co., Armonk, NY, USA) was employed in statistical analyses. Sample size was predetermined using a power analysis: $\alpha=0.05$ and power of 0.8 (SD: 1.22 , mean difference: 2.28 , normal two sided test). The analysis showed that 6 rats per group would be sufficient. The data analysed were presented as (mean \pm SD). The value of $p<0.05$ was regarded as significant in all statistical analyses. Kolmogorov Smirnov normal distribution fit test was used for the data, and non-parametric tests were applied. Kruskal-Wallis test was used in comparing the three groups whereas $\mathrm{P}$ correction Mann-Whitney $\mathrm{U}$ test was used in finding the group from which the differences stemmed. Wilcokson Signed Rank test was employed for three different measurements in-group comparisons, and Friedman test was employed for the 3 measurements.

\section{RESULTS}

Effects of adrenomedullin treatment on serum levels of TNF- $\alpha$ and IL-6

Serum concentrations of TNF- $\alpha$ and IL- 6 were measured with the use of ELISA. On comparing the groups in terms of TNF- $\alpha$ enzyme activity, significant changes were found between groups in the $1^{\text {st }}$ and $4^{\text {th }}$ hour measurements $(p=0.039$ and $p<0.0001$, respectively). Accordingly, the TNF- $\alpha$ enzyme activity in the first hour was found to be significantly higher in $\mathrm{I} / \mathrm{R}$ group than in Sham and AM treatment group ( $p=0.027$ and $p=0.041$, respectively) (Table 1 ). The values of TNF- $\alpha$ levels for the sham and AM treatment group, on the other hand, were found to be similar $(p=0.832)$. In a similar way, the fourth hour TNF- $\alpha$ enzyme activity in I/R group was found to be higher than in the sham and AM treatment group ( $p<0.0001$ and $p<0.0001$, respectively) (Table 1). The levels of TNF- $\alpha$ in sham group were similar to those in the AM treatment group $(p=0.310)$. 
On comparing the groups in terms of IL- 6 enzyme activity, significant differences were found only in the second hour measurements $(p=0.038)$. The second hour IL- 6 enzyme activity in I/R group was found to be significantly higher than in the Sham and AM treatment group $(p=0.025$ and $p=0.028$, respectively). There were no significant differences in the levels of IL-6 for AM treatment group as compared with sham-operated animals $(p=0.864)$.

Table 1. The results of both in-groups and sub-groups

\begin{tabular}{|c|c|c|c|}
\hline & TNF- $\alpha(p g / m)$ & IL-6 (pg/m) & Caspasee-9 \\
\hline \multicolumn{4}{|c|}{ Sham group } \\
\hline $1^{\text {st }}$ hour & $155 \pm 88^{*}$ & $6528 \pm 4044$ & $1.8 \pm 0.4^{*}$ \\
\hline $2^{\text {nd }}$ hour & $204 \pm 27$ & $9770 \pm 2693^{*}$ & $1.6 \pm 0.5^{*}$ \\
\hline $4^{\text {th }}$ hour & $107 \pm 42^{*}$ & $9606 \pm 2682$ & $1.8 \pm 0.4^{*}$ \\
\hline \multicolumn{4}{|c|}{ Control (I/R) group } \\
\hline $1^{\text {st }}$ hour & $228 \pm 124$ & $8007 \pm 2667$ & $2.3 \pm 0.5$ \\
\hline $2^{\text {nd }}$ hour & $489 \pm 616$ & $6713 \pm 1077$ & $2.5 \pm 0.5$ \\
\hline $4^{\text {th }}$ hour & $285 \pm 96$ & $8565 \pm 506$ & $2.8 \pm 0.4$ \\
\hline \multicolumn{4}{|l|}{ AM group } \\
\hline $1^{\text {st }}$ hour & $133 \pm 63^{*}$ & $5990 \pm 1928$ & $1.5 \pm 0.5$ \\
\hline $2^{\text {nd }}$ hour & $220 \pm 79$ & $6916 \pm 2407^{*}$ & $1.3 \pm 0.5^{*}$ \\
\hline $4^{\text {th }}$ hour & $165 \pm 93^{*}$ & $6975 \pm 3272$ & $1.1 \pm 0.4^{*}$ \\
\hline
\end{tabular}

*; Compared with control (I/R) group $\mathrm{p}<0.05$

\#: Compared with sham group $\mathrm{p}<0.05$

Effects of adrenomedullin on lung morphology

As shown in Figure $1 \mathrm{~A}, 1 \mathrm{~B}$ and $1 \mathrm{C}$, lungs of sham-operated animals had a normal microscopic appearance. Comparing the groups according to lung tissue caspase- 9 enzyme activity, significant differences were found between the groups at all measurement times $(p=0.033$ and $p=0.05, p<0.0001$, respectively). The first hour caspase- 9 enzyme activity was found to be significantly higher in I/R group than in sham group $(p=0.011)$. The caspase- 9 enzyme activity in AM treatment group were similar to those in the sham group $(p<0.05)$. The caspase- 9 enzyme activity in the second hour was found to be significantly higher in $\mathrm{I} / \mathrm{R}$ group than in sham and $A M$ treatment group ( $p=0.002$ and $p=0.015$, respectively).
The caspase- 9 enzyme activity in sham and AM treatment group, however, were found to be similar differences $(p=0.291)$. Similarly, the caspase- 9 enzyme activity in the fourth hour was found to be significantly higher in I/R group than in sham and AM treatment group $(p<0.0001$ and $p=0.001$, respectively). For each group, repeated measures of TNF- $\alpha$, IL- 6 and caspase- 9 (Freidman test) and binary (Wilcoxon test) repeated measures were compared, and no analysis was statistically significant.
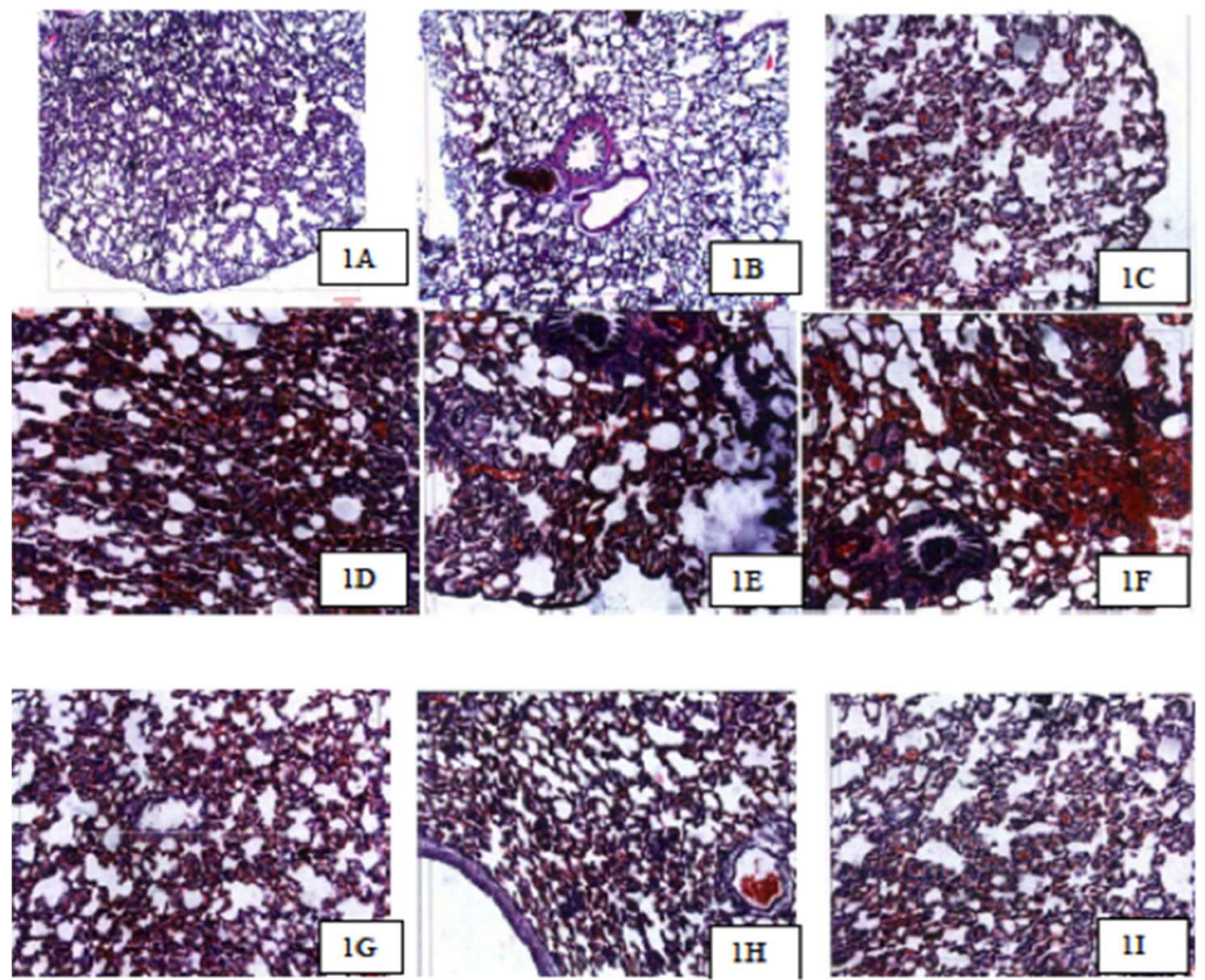

Figure 1A. In sham group $1^{\text {st }}$ hour; the walls of the lung tissue are covered with smooth epithelium; the tissue is formed of alveoli and has a normal lung parenchyma. No pathologic changes are observed in the ductus alveolaris to which the alveoli open. 1B. In sham group $2^{\text {nd }}$ hour; the lung tissue has a normal structure with alveoli containing a terminal bronchiolus of small diameter in the middle and ductus alveolaris. 1C. In sham group $4^{\text {th }}$ hour; the lung tissue has a normal structure with oval or round alveoli; the walls are covered with smooth epithelium. 1D. In hepatic I/R group $1^{\text {st }}$ hour; the lung tissue with sporadic formation of minimal vacuolar structures in the parenchyma of the intraalveolar area where hemorrhagic infiltration has started is striking. $1 \mathrm{E}$. In hepatic I/R group $2^{\text {nd }}$ hour; increased hemorrhagic infiltration, vacuolar, and edematous areas are seen in lung tissue. 1F. In hepatic I/R group $4^{\text {th }}$ hour; the lung tissue: while in one area of the same lung tissue, widespread hemorrhagic infiltration is observed, in the other side, severe damage that has led to lung parenchyma loss is noteworthy. 1G. In AM group $1^{\text {st }}$ hour; the lung parenchyma with terminal bronchiole in the middle and mild hemorrhagic infiltration in the intraalveolar area. $\mathbf{1 H}$. In AM group $2^{\text {nd }}$ hour; the alveoli and ductus alveolaris have a similar appearance as that of the lung tissue, and the degree of hemorrhagic infiltration is reduced compared to that of $1^{\text {st }}$ hour group. 1 . In AM group $4^{\text {th }}$ hour; the characteristics of the lung parenchymal tissue are similar to those of the control group; the alveoli have a normal structure and appearance; the ductus alveolaris have normal width. Hematoxylin andeosin (H\&E x 10). 
As shown in Figure 2A, 2B and 2C, lungs of 1st, 2nd and 4th hour shamoperated animals had a normal microscopic structure. In hepatic I/R group, the findings of ischemia in lung tissue increased gradually between the $1^{\text {st }}$ hour and $4^{\text {th }}$ hour (Figure $2 \mathrm{D}$ and $2 \mathrm{~F}$ ), while in AM treatmeent group that decreased gradually within the same period (Figure $2 \mathrm{G}$ and $2 \mathrm{I}$ ). In the $4^{\text {th }}$ hour of after hepatic I/R, lung apoptosis was seen to be decreased in AM treatment group. The normal level of apoptosis in the sham group with Caspase- 9 increased in severity in I/R group in time starting from the $1^{\text {st }}$ hour
(Figure 2D, 2E and 2F), whereas in $\mathrm{AM}$ treatment group, its severity was similar to that of the sham group (Figure 2G, $2 \mathrm{H}$ and $2 \mathrm{I}$ ). In AM treatment group of $1^{\text {st }}, 2^{\text {nd }}$ and $4^{\text {th }}$ hour; the epithelial cells that form the alveolar wall showed mild to moderate immunreactivity in the epithelial cells that form the alveoli wall, in the cells of intraalveolar area with Caspase-9 (Figure 2G, $2 \mathrm{H}$ and $2 \mathrm{I}$ ). In I/R group, strong immunreactivity was observed in the alveolar epithelial cells, cells of the interepithelial area, and endothelial cells with Caspase-9 starting from the $1^{\text {st }}$ to $4^{\text {th }}$ hour (Figure $2 D, 2 E$ and $2 F$ ). In AM treatment group; however, the degree of immunreactivity ranged from mild to moderate (Figure $2 \mathrm{G}, 2 \mathrm{H}$ and $2 \mathrm{I}$ ).
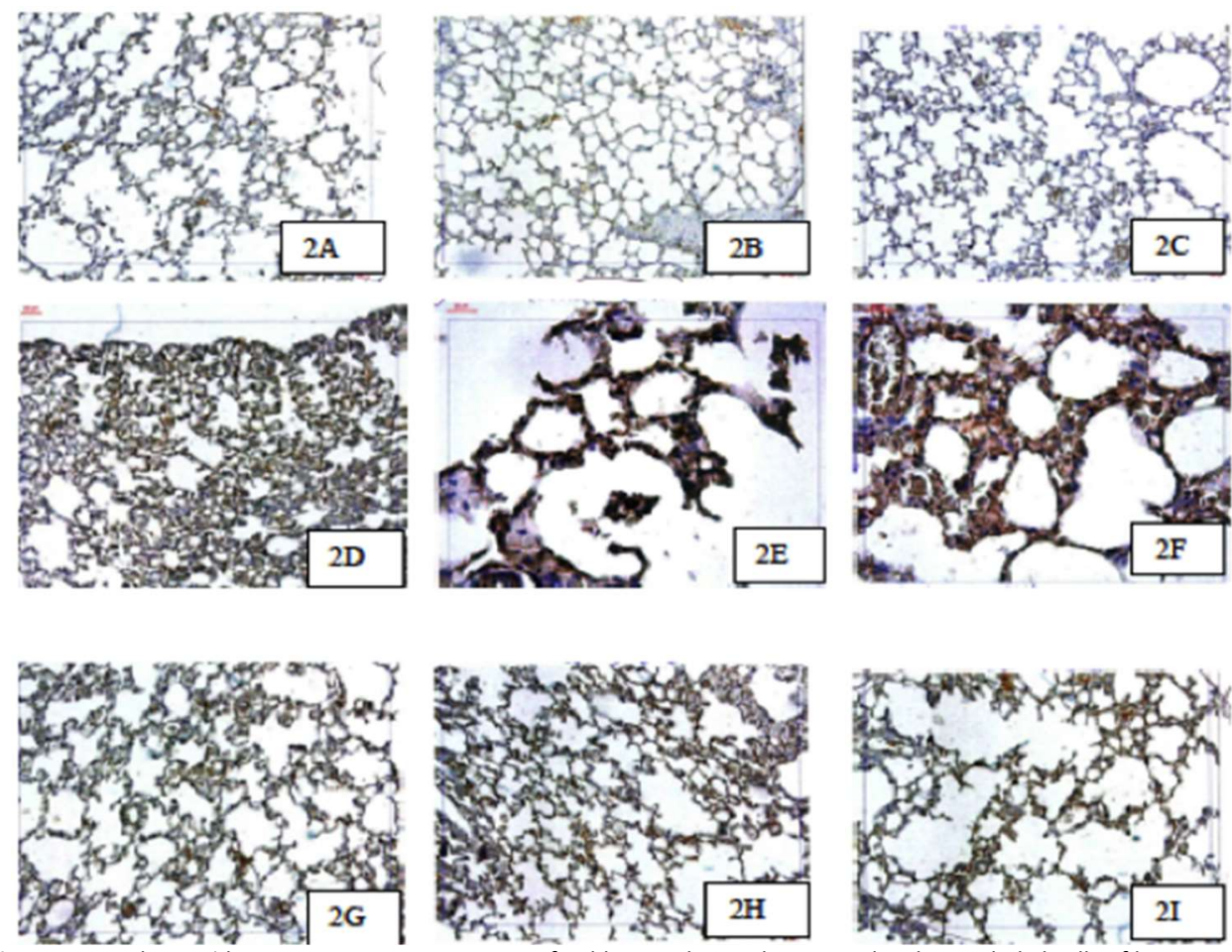

Figure $\mathbf{2 A}$. In sham $1^{\text {st }}$ hour group; immunreactivity of mild to moderate degree in alveolar epithelial cells of lung tissue. 2B. In sham $2^{\text {nd }}$ hour group; moderate immunreactivity in alveolar epithelial cells of lung tissue. 2 C. In sham $4^{\text {th }}$ hour group; mild immunreactivity in alveolar epithelial cells of lung tissue. 2D. In hepatic $\mathbf{~} / \mathrm{R} 1^{\text {st }}$ hour group; strong immunreactivity in endothelial cells and intraalveolar cells of lung tissue. $\mathbf{2 E}$. In hepatic I/R $2^{\text {nd }}$ hour group; strong immunreactivity in alveolar wall of lung tissue. $2 \mathrm{~F}$. In hepatic I/R $4^{\text {th }}$ hour group; strong immunreactivity in alveolar epithelial cells, endothelial cells, and intraalveolar area of lung tissue. 2G. In AM $1^{\text {st }}$ hour group; moderate immunreactivity in epithelial cells of the alveolar wall and intraalveolar area of lung tissue. $\mathbf{2 H}$. In AM $2^{\text {nd }}$ hour group; moderate immunreactivity in epithelial cells of the alveolar wall and intraalveolar area of lung tissue. $\mathbf{2 l}$. In AM $4^{\text {th }}$ hour group; moderate immunreactivity in epithelial cells of the alveolar wall and intraalveolar area of lung tissue (Caspase-9, $\mathrm{x} 10$ ).

\section{DISCUSSION}

Hepatic I/R injury is a mechanism, which may be held responsible for liver failure that may occur after liver transplantation or liver surgery in haemorrhagic or septic shocks and after severe traumas. Organ reperfusion along with the damage caused by ischemia on its own leads to more severe tissue damages. Moreover, liver damage induced by I/R does not only remain in the liver but it also causes non-ischemic remote organ damage. The organs most influenced by I/R induced damage are primarily lungs. Several studies have been conducted to explain the mechanisms underlying the damage. While the studies are based on inflammatory mechanisms, they aim to be able to minimise the damage caused by $I / R$ (15). Thus, the focus of systemic proinflammatory cytokine response is on mechanisms so as to explain the pathophysiology of hepatic I/R injury.

AM -a peptide obtained for the first time by Kitamura et al in 1993 from human phaeochromocytoma cells- are also available in such cells as adrenocortical cells, neurons, glial cells, fibroblasts, macrophages, epithelial cells and various neoplastic cells (16). A study conducted found that there were differences between the AM levels in the pulmonary artery and in the left ventricle, and the study attributed the difference to clearance of AM from the blood by lungs (17). Besides, it was also shown in some other studies that the amount of AM per tissue after AM injection was the highest in the lungs (18). Because the highest amount of AM was in the lung tissues, it was thought that the greatest effect was in the lungs. Therefore, this study aimed to describe the diminishing effects of AM on hepatic $1 / R$ induced lung injury.

Following hepatic I/R, TNF- $\alpha$ and IL- 6 values began to rise, and both reached the maximum value in the second hour. In the fourth hour, however, reduction was observed in both cytokines. The values of TNF- $\alpha$ and IL- 6 in rats especially in groups to which AM was administered were found to be lower than in rats to which hepatic I/R was administered.
Liver Kupffer cells are activated in the second hour, which is regarded as the early phase of $I / R$, and this causes the production of proinflammatory cytokines such as TNF- $\alpha$ and IL-6. This study is in parallel the data presented in the literature. Yet, the data in this study is insufficient to assess the longterm effects of reperfusion.

Excessive release of multiple cytokines was the main reason of the organ inflammatory injury. The release of pro-inflammatory cytokines, such as the activation and migration of TNF- $\alpha, \mathrm{IL}-6, \mathrm{IL}-8$, can induce neutrophils and cause systemic inflammatory damage of various organs (19-21). TNF- $\alpha$ was the one of the highlight cytokine. TNF- $\alpha$, a pleiotropic cytokine, may mediate direct toxicity to mitochondria, and induce apoptotic or necrotic cell death. This secreted TNF- $\alpha$ had local, systemic and remote organ effects, notably on the lung (22). Dwivedi et al. have shown that intestinal $I / R$ induced considerable lung injury, as characterized by lung edema, histopathologic changes, increased proinflammatory cytokines (TNF- $\alpha$ and IL-6) levels in the lungs (18). Colletti et al. have shown that lung and liver injury following hepatic $I / R$ in the rat is increased by exogenous lipopolysaccharide, which also increases hepatic TNF production in vivo and in vitro (23). Administration of AM/ adrenomedullin-binding protein-1 (AMBP-1) after ischemia mitigated lung injury and dramatically downregulated proinflammatory cytokines. Lung injury was also ameliorated by delayed AM/AMBP-1 treatment as evidenced by improvement in lung histology (18). Carrizo et al. demonstrated that administration of AM and AMBP-1 reduced TNF- $\alpha, \mathrm{IL}-1 \beta, \mathrm{IL}-6$, transaminases, lactate and creatinine levels, attenuated tissue injury, and improved survival (24). Kerem et al. have shown that the levels of these cytokines TNF- $\alpha$ and IL$1 \beta$ were found to be significantly high following hepatic $I / R$, however it was seen that the levels of proinflammatory cytokines, apoptosis and necrosis, were significantly decreased by AM treatment (25). 
Many studies making efforts to explain the pathophysiology of the antiinflammatory property of $\mathrm{AM}$ are available, and one of those studies demonstrated that AM stimulated the release of TNF- $\alpha$ and IL- 6 from murine macrophage-like RAQ264.7 cells which were stimulated by endotoxin $(26,27)$. It was demonstrated that the IL-6 levels in circulation were influential in the prediction of ARDS severity (28). IL-6 levels in this study were also observed to reach the highest level especially in the second hour in rats to which $I / R$ was administered. Control group values were reached in the fourth hour group following AM administration. This situation indicated that AM administration mitigated the organ injury by causing IL-6 downregulation, which was a proinflammatory cytokine. Our study is parallel to the one conducted by Dwivedi et al- which demonstrates that AM mitigates lung injury after intestinal $I / R$ (18). In our study, proinflammatory cytokine reached the highest level in the second hour in the hepatic $\mathrm{I} / \mathrm{R}$ group and in the AM administered group, and the cytokine levels began to fall especially after the second hour following AM administration. This situation marks another difference of our study compared to other $\mathrm{I} / \mathrm{R}$ studies in that it shows in what period of time AM administration starts proinflammatory cytokine downregulation.

Lung injury can be further aggravated by increased apoptosis of epithelial cells. Apoptosis is induced through two pathways. The intrinsic pathway is mitochondria-dependent and is activated by reactive oxygen species or cytokines. The extrinsic pathway is dependent on inflammatory molecules, such as TNF- $\alpha$ or Fas-ligand. Activating production of reactive oxygen species via NADPH oxidase, TNF- $\alpha$ contributes to the intrinsic pathway, as well. Both pathways lead to activation of initiator caspases-8 or -9 and finally to activation of effector caspase-3, which is responsible for execution of cell death (29). In our study, in the hepatic I/R group, the findings of ischemia in lung tissue increased gradually between the $1^{\text {st }}$ hour and $4^{\text {th }}$ hour, while in the AM group that decreased gradually within the same period. In the AM groups of $1^{\text {st }}, 2^{\text {nd }}$, and $4^{\text {th }}$ hour the epithelial cells showed mild to moderate immunoreactivity with Caspase-9. In the hepatic I/R group, strong immunoreactivity was observed in the alveolar epithelial cells. However, the degree of immunoreactivity ranged from mild to moderate in AM group. In the $4^{\text {th }}$ hour after reperfusion lung apoptosis was seen to be decreased in AM group. The normal level of apoptosis in sham group with Caspase-9 increased in severity in the hepatic $\mathrm{l} / \mathrm{R}$ group in time starting from the $1^{\text {st }}$ hour, whereas in the AM group, its severity was similar to that of the sham group. Meanwhile, consistent results were obtained from the morphological changes and immunohistochemistry. Setting out from these findings, this study may be said to be significant in that it demonstrates that AM mitigates the apoptosis of pulmonary endothelial cells beginning after the second hour after AM administration in particular, and it has similarities with other studies (30).

In conclusion, we have shown that pulmonary damage associated with hepatic $\mathrm{I} / \mathrm{R}$ as characterized by lung edema and histopathologic changes is mediated by the release of inflammatory mediators such as TNF- $\alpha$ and IL-6. These events lead to histopatholigical consequences such as ischemia, immunoreactivities and apoptosis in lung tissue. Therefore our results showed that administration of AM had a benefical therapeutic effect on hepatic $\mathrm{I} / \mathrm{R}$ induced lung injury.

Acknowledgements: This study was funded by the Gazi University Scientific Research Program which number is 01/2006-38.

\section{Conflict of interest:}

The authors declared that there is no conflict of interest.

\section{REFERENCES}

1. Ohashi I, Kaku R, Fuji H, Nakatsuka H, Matsumi M, Morita K. Severe acute pulmonary edema during living related liver transplantation surgery. Masui The Japanese journal of anesthesiology. 2004;53:925-8.

2. Yao W, Li H, Luo G, Li X, Chen C, Yuan D, Chi X, Xia Z, Hei Z. SERPINB1 ameliorates acute lung injury in liver transplantation through ERK1/2-mediated STAT3dependent HO-1 induction. Free Radic Biol Med 2017; 108: 542-53.

3. Kimura $\mathrm{N}$, Muraoka R, Horiuchi $\mathrm{T}$, Tabo T, Uchinami M, Yokomachi J, et al. Intermittent hepatic pedicle clamping reduces liver and lung injury. The Journal of surgical research. 1998;78:11-7.

4. Chi X, Guo N, Yao W, Jin Y, Gao W, Cai J, Hei Z. Induction of heme oxygenase-1 by hemin protects lung against orthotopic autologous liver transplantation-induced acute lung injury in rats. J Transl Med 2016; 14: 35.

5. Chen Z, Ding T, Ma CG. Dexmedetomidine (DEX) protects against hepatic ischemia/reperfusion (I/R) injury by suppressing inflammation and oxidative stress in NLRC5 deficient mice. Biochem Biophys Res Commun 2017; 493: 1143-50.

6. Chan KC, Lin CJ, Lee PH, CHen CF, Lai YL, Sun WZ, Cheng YJ. Propofol attenuates the decrease of dynamic compliance and water content in the lung by decreasing oxidative radicals released from the reperfused liver. Anesth Analg 2008; 107: $1284-9$.
7. Liu Z, Wang Y, Wang Y, Ning $Q$, Zhang Y, Gong C, Zhao W, Jing G, Wang $Q$. Dexmedetomidine atten- uates inflammatory reaction in the lung tissues of septic mice by activating cholinergic anti-inflammatory pathway. Int Immunopharmacol 2016; 35: 210-216.

8. Cui J, Zhao H, Yi B, Zeng J, Lu K, Ma D. Dexmedetomidine attenuates BilirubinInduced lung alveolar epithelial cell death in vitro and in vivo. Crit Care Med 2015; 43: e356-e368.

9. Yang J, Wu R, Qiang X, Zhou M, Dong W, Ji Y, et al. Human adrenomedullin and its binding protein attenuate organ injury and reduce mortality after hepatic ischemia-reperfusion. Ann Surg. 2009;249:310-7.

10. Kitamura K, Kangawa $K$, Kawamoto $M$, Ichiki $Y$, Nakamura $S$, Matsuo $H$, et al. Adrenomedullin: a novel hypotensive peptide isolated from human pheochromocytoma. Biochemical and biophysical research communications. 1993;192:553-60.

11. Martinez A, Miller MJ, Unsworth EJ, Siegfried JM, Cuttitta F. Expression of adrenomedullin in normal human lung and in pulmonary tumors. Endocrinology. 1995;136:4099-105.

12. Garcia MA, Martin-Santamaria $S$, de Pascual-Teresa B, Ramos A, Julian $M$, Martinez A. Adrenomedullin: a new and promising target for drug discovery. Expert opinion on therapeutic targets. 2006;10:303-17.

13. Agorreta J, Zulueta JJ, Montuenga LM, Garayoa M. Adrenomedullin expression in a rat model of acute lung injury induced by hypoxia and LPS. American journal of physiology Lung cellular and molecular physiology. 2005;288:L536-45.

14. Itoh T, Obata H, Murakami S, Hamada K, Kangawa K, Kimura $\mathrm{H}$, et al. Adrenomedullin ameliorates lipopolysaccharide-induced acute lung injury in rats. American journal of physiology Lung cellular and molecular physiology. 2007:293:L446-52.

15. Ge M, Yao W, Yuan D, Zhou S, Chen X, Zhang Y, Li H, Xia Z, Hei Z. Brg1-mediated Nrf2/HO-1 pathway activation alleviates hepatic ischemia-reperfusion injury. Cell Death Dis 2017; 8: e2841.

16. Takahashi K. Adrenomedullin from a pheochromocytoma to the eye: implications of the adrenomedullin research for endocrinology in the 21st century. The Tohoku journal of experimental medicine. 2001;193:79-114.

17. Dupuis J, Caron A, Ruel N. Biodistribution, plasma kinetics and quantification of single-pass pulmonary clearance of adrenomedullin. Clinical science (London, England : 1979). 2005;109:97-102.

18. Dwivedi AJ, Wu R, Nguyen E, Higuchi S, Wang H, Krishnasastry K, et al. Adrenomedullin and adrenomedullin binding protein-1 prevent acute lung injury after gut ischemia-reperfusion. Journal of the American College of Surgeons. 2007;205:284-93.

19. Thomaz NF, Koike MK, Abrahao MS, Carillo NF, Pereira RK, Machado JL, Montero EF. Ischemic preconditioning attenuates remote pulmonary inflammatory infiltration of diabetic rats with an in- testinal and hepatic ischemiareperfusion injury. Acta Cir Bras 2013; 28: 174-8.

20. Bae HB, Jeong CW, Li M, Kim HS, Kwak SH. Effects of urinary trypsin inhibitor on lipopolysaccha- ride-induced acute lung injury in rabbits. Inflam- mation 2012; 35: $176-82$.

21. Chan LP, Liu C, Chiang FY, Wang LF, Lee KW, Chen WT, Kuo PL, Liang CH. IL-8 promotes inflamma- tory mediators and stimulates activation of p38 MAPK/ERKNF-kappaB pathway and reduction of JNK in HNSCC. Oncotarget 2017; 8: 5637588.

22. Teoh NC. Hepatic ischemia reperfusion injury: Contemporary perspectives on pathogenic mechanisms and basis for hepatoprotection-the good, bad and deadly. Journal of gastroenterology and hepatology. 2011;26 Suppl 1:180-7.

23. Colletti LM, Green M. Lung and liver injury following hepatic ischemia/reperfusion in the rat is increased by exogenous lipopolysaccharide which also increases hepatic TNF production in vivo and in vitro. Shock (Augusta, Ga). 2001;16:312-9.

24. Carrizo GJ, Wu R, Cui X, Dwivedi AJ, Simms HH, Wang P. Adrenomedullin and adrenomedullin-binding protein-1 downregulate inflammatory cytokines and attenuate tissue injury after gut ischemia-reperfusion. Surgery. 2007;141:245-53. 25. Kerem M, Bedirli A, Pasaoglu H, Ofluoglu E, Yilmazer D, Salman B, et al. Effect of adrenomedullin on hepatic damage in hepatic ischaemia/reperfusion injury in rats. Liver international : official journal of the International Association for the Study of the Liver. 2008;28:972-81.

26. Wu R, Zhou M, Wang P. Adrenomedullin and adrenomedullin binding protein-1 downregulate TNF-alpha in macrophage cell line and rat Kupffer cells. Regulatory peptides. 2003;112:19-26.

27. Yang $S$, Zhou M, Fowler DE, Wang P. Mechanisms of the beneficial effect of adrenomedullin and adrenomedullin-binding protein-1 in sepsis: down-regulation of proinflammatory cytokines. Critical care medicine. 2002;30:2729-35.

28. Remick DG, Bolgos GR, Siddiqui J, Shin J, Nemzek JA. Six at six: interleukin-6 measured $6 \mathrm{~h}$ after the initiation of sepsis predicts mortality over 3 days. Shock (Augusta, Ga). 2002;17:463-7.

29. Galani V, Tatsaki E, Bai M, Kitsoulis P, Lekka M, Nakos G, et al. The role of apoptosis in the pathophysiology of Acute Respiratory Distress Syndrome (ARDS): an up-to-date cell-specific review. Pathology, research and practice. 2010;206:14550.

30. Sata $M$, Kakoki M, Nagata $D$, Nishimatsu $H$, Suzuki E, Aoyagi $T$, et al. Adrenomedullin and nitric oxide inhibit human endothelial cell apoptosis via a cyclic GMP-independent mechanism. Hypertension (Dallas, Tex : 1979). 2000;36:83-8. 